\title{
PENDAMPINGAN PERMASALAHAN HUKUM WARIS DI DESA KEPULUNGAN KECAMATAN GEMPOL, KABUPATEN PASURUAN
}

\author{
Arief Syahrul Alam, Dwi Elok Indriastuty, Fifin Dwi Purwaningsih \\ ${ }^{1}$ Fakultas Hukum Universitas Wijaya Putra \\ ${ }^{2}$ Fakultas Hukum Universitas Wijaya Putra \\ ${ }^{3}$ Fakultas Psikologi Universitas Wijaya Putra \\ sahrulalam@uwp.ac.id \\ dwielok@uwp.ac.id \\ fifin@uwp.ac.id
}

\begin{abstract}
Abstrak
Berbagai permasalahan hukum keluarga khususnya dibidang hukum waris seringkali menimbulkan sengketa hukum yang berkepanjangan sampai dengan anak cucu sebagai generasi penerus suatu keluarga. Bahkan terkadang perselisihan waris dapat menimbulkan putusnya tali persaudaraan. Ironisnya beberapa sengketa yang berkaitan dengan hukum waris berlangsung hingga turun temurun. Hasil dari pemetaan di lapangan ditemukan beberapa permasalahan waris yang disebabkan beberapa hal, pertama tidak memahami pentingnya hukum waris, kurangnya pengetahuan terhadap proses pengurusan penetapan ahli waris dan yang ketiga kurangnya pemahaman berkaitan dengan sengketa waris.
\end{abstract}

Kegiatan ini dilaksanakan selama 7 (tujuh) hari yakni pada tanggal 13-19 April 2019 dengan sasaran masyarakat di Desa Kepulungan, Kecamatan Gempol, Kabupaten Pasuruan seluruhnya berjumlah 40 orang. Tujuan dari program pendampingan permasalahan hukum waris ini adalah untuk meningkatkan pemahaman masyarakat terhadap hukum waris serta mengidentifikasi permasalahan dan membantu penyelesaian sengketa waris. Metode yang digunakan dalam kegiatan ini adalah memberikan sosialisasi berkaitan dengan system hukum waris yang berlaku di Indonesia, memetakan permasalahan sengketa-sengketa waris, dan melakukan pendampingan penyelesaian sengketa waris. Hasil dari kegiatan ini menunjukkan peningkatan kesadaran masyarakat terhadap pengaturan hukum waris, pemahaman tentang prosedur permohonan penetapan ahli waris dan penyelesaian sengketa waris.

Kata kunci: Hukum Waris, Pendampingan Hukum, Sengketa Waris

\section{PENDAHULUAN}

Pada dasarnya hukum waris merupakan salah satu bagian dari hukum perdata atau dapat dikatakan sebagai sub-sistem dari hukum keluarga. Hukum waris timbul dari peristiwa hukum yang dikenal dengan kematian. Meskipun konsep tersebut terdapat perbedaaan dengan prinsip dalam hukum adat, dimana proses pewarisan tidak selalu didahului dengan adanya kematian. Namun yang terpenting adalah akibat hukum dari suatu kematian seseorang, secara hukum akan beralihnya kepengurusan dan kelanjutan atas hak-hak dan kewajiban-kewajiban dari pihak yang meninggal tersebut. Secara pokok dalam hukum waris terdapat 3 (tiga) unsur yakni adanya harta peninggalan atau kekayaan pewaris yang disebut dengan warisan, adanya pewaris yaitu yang menguasai atau memiliki harta warisan dan adanya ahli waris yakni 
orang yang menerima pengalihan melalui penerusan atau pembagian harta warisan.

Permasalahan hukum yang sering terjadi pada suatu keluarga berawal dari kematian seseorang khususnya yang berkaitan dengan pengurusan hak kepemilikan dari orang yang meninggal tersebut. Bahkan seringkali permasalahan tersebut berlarut-larut dan tidak terselesaikan bahkan sampai menimbulkan sengketa hukum di pengadilan. Salah satu permasalahan hukum yang sering terjadi disuatu keluarga adalah berasal dari permasalahan pewarisan atau pembagian harta waris yang dianggap tidak adil. Kekurang pahaman terhadap pengaturan tentang waris atau prosedur permohonan penetapan ahli waris menjadikan penyelesaian waris menjadi berlarut-larut.

Dalam program pengabdian kepada masyarakat yang dilakukan oleh Dosen Fakultas Hukum, Universitas Wijaya Putra ini, dilakukan pendampingan terhadap permasalahan hukum waris yang bertujuan untuk meningkatkan pemahaman pada masyarakat terhadap hukum waris serta mengidentifikasi permasalahan dan membantu penyelesaian sengketa waris. Kegiatan ini dilaksanakan selama 7 hari yakni pada tanggal 13-19 April 2019 dengan sasaran masyarakat di Desa Kepulungan, Kecamatan Gempol, Kabupaten Pasuruan yang berjumlah 40 orang.

Dari hasil pemetaan yang dilakukan terhadap kelompok masyarakat di Desa Kepulungan, Kecamatan Gempol, Kabupaten Pasuruan, ditemukan beberapa permasalahan antara lain tidak memahami pengaturan hukum yang berkaitan dengan waris, tidak memahami prosedur hukum dalam pengajuan penetapan ahli waris serta tidak memahami prosedur penyelesaian sengketa waris. Berangkat dari pemetaan permasalahan yang telah dilakukan maka tahapan selanjutnya adalah upaya sosialisasi tentang pengaturan hukum waris di Indonesia, pendampingan pengurusan penetapan ahli waris serta pendampingan penyelesaian sengketa waris.

\section{METODE}

Metode yang digunakan adalah melalui sosialisasi tentang pentingnya pemahaman akan pengaturan hukum waris di Indonesia, dari sosialisasi tersebut selanjutnya di lakukan pemetaan terhadap jenis atau karaktersitik permasalahan dari masing-masing sengketa waris yang terjadi. Hasil dari pemetaan akan dilakukan pendampingan pengurusan penetapan ahli waris serta pendampingan penyelesaian sengketa waris.

Rencana aktifitas tersebut dilakukan dengan tahapan kegiatan sebagai berikut :

1. Tahap perencanaan dan penyusunan program

Pada tahap ini dimulai dengan pemilihan lokasi kegiatan dan mengidentifikasi kebutuhan dari masyarakat. Selain itu dalam tahap ini di rumuskan rencana kegiatan sampai dengan penyusunan program kegiatan, kerangka waktu pelaksanaan kegiatan serta penyusunan anggaran biaya yang diperlukan. Setelah ditetapkan lokasi kegiatan serta dilakukan identifikasi permasalahan maka tahap selanjutnya disusun materi kegiatan. Materi kegiatan

Ekonomi, Sosial, dan Budaya 
yang berhasil diperoleh dari hasil identifikasi, salah satunya adalah berkaitan dengan hukum kewarisan. Kekurangpahaman masyarakat terhadap permasalahan hukum waris menjadikan berbagai permasalahan antara lain tidak terselesaikannya dengan tuntas terhadap harta waris dan timbulnya sengketa waris diantara pada anggota keluarga.

\section{Tahap Pelaksanaan Program}

Pada tahap perlaksanaan program diawali dengan sosialisasi tentang system hukum waris yang berlaku di Indonesia. Materi sosialisasi hukum waris meliputi pemahaman terhadap aspek pluralisme hukum waris, pilihan hukum waris, hak mewaris serta proses dan prosedur pengurusan penetapan ahli waris. Disamping materi sosialisasi tentang waris dalam pelaksanaan program juga dilakukan asistensi tentang penyusunan permohonan penetapan ahli waris serta penyelesaian terhadap sengketa waris.

\section{Tahap penyusunan laporan kegiatan}

Pada tahap akhir adalah tahap penyusunan laporan kegiatan dengan melakukan pengumpulan seluruh materi dan dokumentasi kegiatan serta penyusunan laporan keuangan kegiatan. Dari laporan yang disusun dapat disimpulkan bahwa seluruh kegiatan telah sesuai dengan perencanaan sebagaimana yang dirumuskan. Disamping itu dalam laporan kegiatan di rumuskan saran terkait dengan perencanaan kegitan selanjutnya dalam rangka peningkatan kualitas dan kuantitas kegiatan pengabdian masyarakat.

\section{HASIL DAN PEMBAHASAN}

Hasil dan pembahasan dalam kegiatan ini diperoleh hasil yang sesuai dengan metode dan tahapan pelaksanaan sebagaimana telah dirumuskan yakni perencanaan dan penyusunan program, sosialisasi dan pemetaan permasalahan mulai dengan jenis atau karaktersitik hukum waris yang berlaku di Indonesia. Disamping itu, dari hasil dari pemetaan dilakukan pendampingan pengurusan penetapan ahli waris serta pendampingan penyelesaian sengketa waris, yang dapat diuraikan dengan sistematika sebagai berikut :

\section{Sosialisasi Sistem Hukum Waris yang berlaku di Indonesia.}

Dalam sosialisasi tentang system hukum waris yang berlaku di Indonesia, materi pertama yang disampaikan adalah berkaitan dengan pengaturan hukum tentang waris. Sebagaimana diketahui, sistem hukum waris di Indonesia sampai dengan saat ini masih berlaku pluralisme hukum (legal pluralism). Pluralisme hukum yang dimaksudkan adalah substansi dan mekanisme penyelesaian sengketa atau pembagian waris belum ada unifikasi hukum di Indonesia. Hal ini disebabkan karena dalam pengaturan hukum waris di Indonesia masih mendasarkan pada 3 (tiga) sistem hukum yakni hukum adat, hukum agama Islam dan hukum negara.

Ekonomi, Sosial, dan Budaya 
Berlakunya hukum waris Islam sebagai hukum materiil bagi sebagian masyarakat yang beragama Islam didasarkan pada Buku II tentang Kewarisan yang tertuang dalam Instruksi Presiden (Inpres) Nomor 1 Tahun 1991 tentang Kompilasi Hukum Islam (KHI). Sedangkan hukum waris negara berlaku ketentuan dalam Burgerlijk Wetboek (BW) yang berlaku berdasarkan pada Pasal II Aturan Peralihan UUD NRI Tahun 1945 yang menyatakan bahwa segala badan negara dan peraturan yang ada masing langsung berlaku selama belum diadakan yang baru. Selanjutnya terhadap pemberlakukan hukum adat, dibeberapa daerah di Indonesia masih diberlakukan, hal itu dikarenakan pemahaman sebagian masyarakat masih mempercayai khususnya yang berkaitan dengan sengketa waris akan berjalan lebih harmonis dibandingkan dengan dua sistem hukum lainnya.

Pandangan tentang pluralisme hukum dalam waris sendiri dapat dimaknai sebagai suatu situasi dimana berlakunya lebih dari dua sistem hukum yang berfungsi serta bekerja secara berdampingan dalam suatu bidang kehidupan sosial. Pandangan yang lain menyatakan bahwa pluralisme hukum adalah suatu situasi dimana dua atau lebih sistem hukum berinteraksi dalam satu kehidupan sosial. Dari kedua pengertian tersebut dapat di disimpulkan bahwa pengertian dari pluralisme adalah berlakunya lebih dari dua sistem hukum tertentu dalam wilayah hukum tertentu, dimana masyarakat di berikan pilihan hukum untuk memilih salah satu dari sistem hukum yang berlaku tersebut. Pilihan tersebut sesuai dengan latarbelakang baik dari segi agama yang dianutnya maupun sesuai dengan adat istiadat yang berlaku di daerah tertentu.

Berkaitan dengan hukum kewarisan yang merupakan himpunan aturan hukum yang mengatur tentang siapa ahli waris yang berhak mewarisi harta peninggalan pewaris. Pada prinsipnya menurut hukum Islam pewarisan terjadi didahului dengan adanya kematian. Kemudian orang yang meninggal tersebut meninggalkan harta warisan yang akan dibagikan kepada ahli warisnya. Berbeda dengan prinsip dalam hukum adat, prosedur pewarisan tidak selalu didahului adanya kematian. Akan tetapi pembagian warisan dalam hukum Islam dan hukum adat dapat berjalan beriringan seperti prinsip pembagian sepikul segendong.

Materi yang kedua, yang disampaikan dalam sosialisasi disamping aspek pluralisme pengaturan hukum waris, adalah materi yang tentang harta warisan dalam perspektif hukum islam dan dalam perpektif hukum adat. Dalam hukum adat dikenal juga pluralisme sistem kekeluargaan khususnya yang terkait dengan system penarikan garis keturunan. Dimana disuatu daerah berbeda sistem kekeluargaannya dengan daerah lainnya. Di Indonesia pada umumnya dikenal adanya tiga sistem kekeluargaan, yakni yang pertama sistem patrilineal, dimana keturunan diambil dari garis Bapak menjadi penentu dalam keturunan anak cucu. Dengan demikian dalam sistem patrilineal kaum perempuan tidak menjadi saluran darah yang menghubungkan keluarga. Seseroang perempuan yang kawin dengan laki-laki ikut dengan suaminya dan anaknya menjadi keluarga si ayah. Konsekuensinya dalam hukum waris, sistem pertalian ini lebih 
mengutamakan garis keturunan dari anak laki-laki daripada anak perempuan. Sistem pertalian patrilineal berlaku dibeberapa daerah di Indonesia seperti Nias, Gayo, Batak, sebagian Lampung, Bengkulu, Maluku dan Timor.

Selanjutnya system matrilineal, adalah keturuan yang berasal dari Ibu, sehingga hanya pertalian yang barasal dari garis darah Ibu menjadi ukuran dan merupakan suatu persekutuan hukum. Sesuai dengan persekutuannya, sistem matrilineal lebih didominasi atau dihargai ahli waris dari pihak perempuan daripada pihak laki-laki. Sejauh masih ada anak perempuan, akan diutamakan sebagai ahli waris daripada anak laki-laki. Sistem matrilineal terdapat di Minangkabau, Kerinci, Semendo dan beberapa daerah di Indonesia Timur. Sistem berikutnya adalah sistem bilateral atau parental, merupakan pertalian darah dilihat dari kedua sisi baik sisi Bapak maupun Ibu. Pada persekutuan bilateral, kedua garis keturunan dianggap sama-sama penting dan sama kedudukannya antara suami dan istri. Sistem bilateral di kenal dibeberapa daerah seperti Jawa, Madura, Sumatera Timur, Riau, Aceh, Sumatera Selatan, Kalimantan, Sulawesi, Ternate dan Lombok.

Dari sosialisasi yang dilakukan pada tanggal 13 April 2019, diperoleh gambaran bahwa seluruh masyarakat di Desa Kepulungan, Kecamatan Gempol, Kabupaten Pasuruan beragama Islam serta berasal dari suku Jawa. Dengan demikian maka dalam masalah waris menggunakan garis keturunan bilateral dalam pola pembagian waris serta pembagian waris sesuai dengan hukum Islam sebagaimana diatur dalam Buku II tentang Kewarisan yang tertuang dalam Instruksi Presiden (Inpres)
Nomor 1 Tahun 1991 tentang Kompilasi Hukum Islam (KHI).

Selain itu pada tahap pelaksanaan sosialisasi juga dilakukan pemetaan terhadap potensi permasalahan tentang waris. Hasil pemetaan diperoleh data bahwa dari 40 peserta yang mengikuti sosialisasi teridentifikasi 5 orang atau keluarga akan melakukan pembagian waris yang diawali dengan permohonan penetapan ahli waris dan 1 keluarga dalam proses sengketa waris. Upaya untuk melakukan permohonan penetapan waris dan penyelesaian sengketa waris tersebut mengemuka setelah para peserta memahami arti penting hukum waris dan sebagai upaya untuk memberikan kepastian hukum dan perlindungan hukum terhadap para ahli waris.

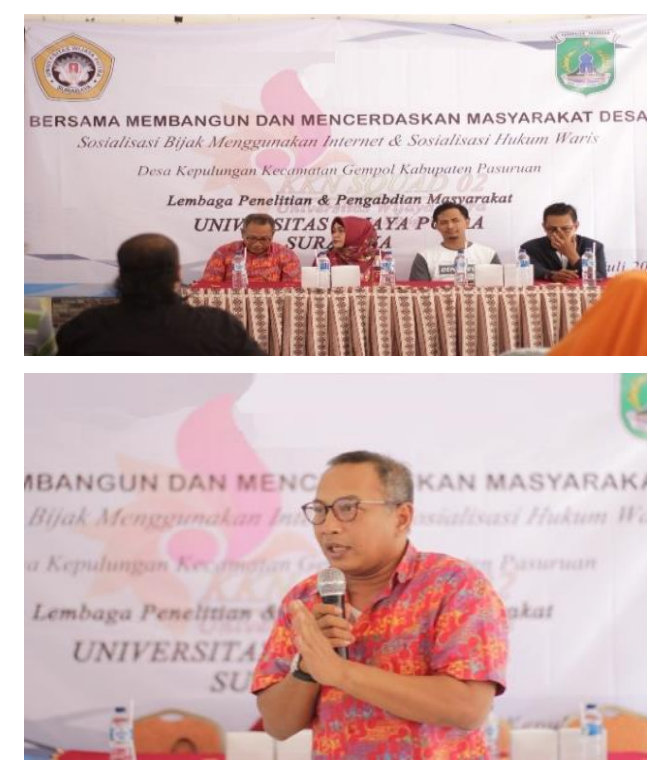

Gambar 1 dan 2 : Sosialisasi dan Pendampingan Penyelesaian Sengketa Waris

Ekonomi, Sosial, dan Budaya 


\section{Pendampingan Penyusunan Permohonan Penetapan Ahli Waris}

Secara normatif, pengaturan tentang prosedur permohonan ahli waris di atur dalam pasal 49 huruf b Undang-undang Nomor 3 Tahun 2006 tentang Perubahan atas Udang-undang Nomor 7 Tahun 1989 tentang Peradilan Agama. Dalam pasal 49 UU Peradilan Agama menentukan : Bahwa pengadilan agama bertugas dan berwenang memeriksa, memutus, dan menyelesaikan perkara tingkat pertama antara orang-orang yang beragama Islam di bidang :
a. Perkawinan;
b. Waris;
c. Wasiat;
d. Hibah;
e. Wakaf;
f. Zakat;
g. Infaq;
h. Shadaqah; dan
i. Ekonomi syariah.

Dalam penjelasan pasal 49 huruf $b$ diuraikan bahwa "...yang dimaksud dengan "waris" adalah penentuan siapa yang menjadi ahli waris, penentuan mengenai harta peninggalan, penentuan bagian masing-masing ahli waris, dan melaksanakan pembagian harta peninggalan tersebut, serta penetapan pengadilan atas permohonan seseorang tentang penentuan siapa yang menjadi ahli waris, penentuan bagian masingmasing ahli waris".

Dari ketentuan pasal 49 Undangundang No. Nomor 3 Tahun 2006, sangat jelas bahwa yang berwenang untuk memeriksa, memutus, dan menyelesaikan perkara tingkat pertama antara orang-orang yang beragama Islam berada pada Pengadilan Agama termasuk perkara pewarisan. Upaya hukum yang dapat dilakukan oleh para ahli waris sejauh ini adalah pengajuan permohonan penetapan ahli waris di Pengadilan Agama.

Secara teoritis, penetapan atau beschiking dalam Bahasa Belanda merupakan produk peradilan yang bersifat jurisdictio voluntaria, dan berbeda dengan putusan yang memiliki makna jurisdiction contentiosa. Karena dalam penetapan tidak ditemukan adanya pihak lawan, bentuk penetapan pihaknya hanya satu yaitu Pemohon meskipun pihak pemohonnya bisa lebih dari satu. Sifat dari isi penetapan bersifat declaratoir atau constitutif karena bentuk penetapan diajukan oleh para pihak tidak didasarkan pada suatu sengketa. Hal ini berbeda dengan sifat dari putusan pengadilan yang bersifat condemnatoir atau penghukuman yang berangkat dari suatu sengketa dan berbentuk gugatan. Sifat dasar dari penetapan tidak mempunyai nilai eksekutorial maupun nilai pembuktian dan penetapan pengadilan hanya mengikat pada pemohon beserta dengan ahli warisnya dan pada pihak yang memperoleh manfaat dari padanya. Meskipun demikian penetapan merupakan produk pengadilan sebagai bagian dari akta otentik, akan tetapi nilai pembuktiannya berbeda dengan putusan yang bersifat condemnatoir. Hal ini disebabkan karena dalam pemeriksaan terhadap permohonan bersifat ex parte atau sepihak. Nilai kekuatan pembuktian terhadap produk pengadilan berbentuk penetapan hanya mengikat pada pihak pemohon saja dan tidak mempunyai kekuatan mengikat pada orang lain atau pihak ketiga.

Dari uraian teoritis tentang permohonan penetapan ahli waris, sejauh belum atau tidak ada sengketa terhadap obyek warisan maka seyogjanya diajukan permohonan yang 
nantinya pada Pengadilan Agama memiliki kompetensi untuk menerbitkan penetapan. Penetapan ahli waris merupakan penentuan terhadap siapa yang berhak menjadi ahli waris serta pembagian harta warisan yang ditinggalkan. Kecuali dalam hal terjadi sengketa waris, maka harus dilakukan dalam bentuk gugatan waris baik terhadap subjek maupun obyek warisan tersebut. Adapun produk Pengadilan Agama yang akan diterbitkan dalam suatu gugatan berupa putusan pengadilan.

Adapun syarat-syarat yang harus dipersiapkan untuk melengkapi dokumen permohonan ahli waris selain dokumen terkait harta warisan, calon pemohon harus melengkapi dokumendekumen sebagai berikut :

1. Surat Permohonan Waris

2. Foto copy KTP Pemohoan dan semua ahli waris ;

3. Foto copy akta nikah pewaris;

4. Foto copy akta kelahiran semua anak dari pewaris ;

5. Foto copy surat kematian orang tua pewaris;

6. Surat keterangan dari kelurahan yang menyatakan dengan sebenarnya bahwa ahli waris adalah suami/istri/anak dari almarhum, yang diperlukan untuk mengurus penetapan ahli waris di Pengadilan Agama; dan

7. Foto copy surat keterangan ahli waris.

Setelah para calon pemohon melengkapi seluruh dokumen untuk mengajukan permohonan, di lakukan asistensi untuk menyusun surat permohonan yang diajukan kepada Pengadilan Agama, Kabupaten Pasuruan. Dan sampai dengan program kegiatan ini selesai ke 5 (lima) permohonan masih dalam tahap persidangan dan menunggu penetapan dari Pengadilan. Namun setidaknya dengan diterbitkannya penetapan oleh Pengadilan Agama memberikan kepastian hukum bagi para ahli waris yang mengajukan permohonan tersebut.

\section{Pendampingan \\ Sengketa Waris \\ Penyelesaian}

Pada dasarnya tahapan terjadinya suatu sengketa dapat dibagi menjadi 3 (tiga) karakter sengketa yaitu :

1. Pra konflik dimana keadaan yang mendasari rasa tidak puas seseorang ;

2. Konflik yaitu keadaan dimana para pihak menyadari atau mengetahui tentang adanya perasaan tidak puas tersebut;

3. Sengketa adalah keadaan dimana konflik tersebut dinyatakan di muka umum atau dengan melibatkan pihak ketiga.

Dalam penyelesaian kasus perselisihan waris di satu keluarga sebagaimana dijelaskan sebelumnya harus mempertimbangkan tentang sistem dan pengaturan waris di Indonesia. Hukum waris yang berlaku di Indonesia adalah sistem yang diadopsi dari sistem bilateral, yaitu melihat pertalian dara dari kedua sisi, yakni dari sisi bapak dan ibu serta kedua sisi keturunan sama-sama dianggap penting. Sistem ini yang meletakkan dasar-dasar persamaan kedudukan antar suami dan istri di dalam keluarga masing-masing. Sebagai contoh penguasaan harta dalam perkawinan menjadi harta bersama sedangkan harta bawaan dari masing-masing suami dan istri dan harta yang diperoleh masingmasing sebagai hadiah atau warisan adalah dibawah penguasaan masing- 
masing sepanjang para pihak tidak menentukan lain. Ketentuan tersebut diatur dalam pasal 35 ayat (1) dan (2) Undang-undang Nomor 1 Tahun 1974 tentang Perkawinan.

$\begin{array}{ccc} & \text { Demikian juga mengenai hukum } \\ \text { yang } & \text { dipergunakan dalam }\end{array}$ menyelesaikan sengketa waris dapat menggunakan hukum adat, hukum agama maupun hukum negara. Hal ini dimungkinkan apabila dalam masyarakat tertentu menggunakan penyelesaian sengketa warisan berbasis pada penerapan pluralisme hukum. Pada umumnya pola pembagian harta warisan terbagi menjadi dua model yaitu bila tidak terjadi konflik maka dilakukan dengan cara musyawarah oleh para ahli waris, sedangkan apabila terjadi sengketa diantara para ahli waris baik yang berkaitan dengan kedudukan ahli waris maupun jumlah pembagian masing-masing ahli waris, maka pembagiannya diselesaikan melalui pengadilan. Penyelesaian perselisihan waris di pengadilan pada dasarnya merupakan optimum remedium atau upaya terakhir apabila jalur penyelesaian secara musyawarah mengalami kebuntuan.

Kalaupun harus diselesaikan di pengadilan, upaya yang masih dimungkinkan untuk dilakukan sebagai jalan penyelesaian sengketa yaitu perdamaian yang dituangkan dalam akta perdamaian (acta van dading) antara pada pihak yang berperkara. Kekuatan hukum dari akta perdamaian tersebut sama dengan kekuatan hukum dari putusan yang telah memiliki kekuatan hukum tetap atau in kracht van gewijsde. Artinya sama-sama memiliki nilai eksekutorial (executorial kracht), apabila terhadap acta van dading tersebut tidak dilaksanakan secara sukarela oleh masing-masing atau salah satu pihak yang berperkara dan dapat dilaksanakan secara paksa atau dieksekusi.

Dalam penyelesaian yang terjadi di Desa Kepulungan, Kecamatan Gempol, Kabupaten Pasuruan, direkomendasikan untuk diselesaikan di luar pengadilan artinya diselesaikan secara musyawarah berdasarkan prinsip kekeluargaan dengan beberapa pertimbangan :

1. Penyelesaian secara musyawarah oleh para ahli waris merupakan cerminan masyarakat yang menghormati hukum adat yang tumbuh dan berlaku didaerahnya serta mempertimbangkan dan memperhatikan nilai-nilai yang hidup dalam masyarakat;

2. Sebagian besar masyarakat memandang pengadilan sebagai lembaga terakhir sebagai wahana penyelesaian sengketa waris. Karena masyarakat berpandangan bahwa menyerahkan permasalahan sengketa waris di pengadilan sama dengan menyerahkan atau memperlihatkan aib keluarga kepada pihak ketiga yang seharusnya tidak semestinya tidak harus mengetahui akar permasalahan para pihak.

\section{SIMPULAN DAN SARAN}

\section{SIMPULAN}

Dari uraian pada bagian
sebelumnya tentang pelaksanaan kegiatan program pendampingan permasalahan hukum waris di Desa Kepulungan, Kecamatan Gempol, Kabupaten Pasuruan dapat ditarik simpulan sebagai berikut : 
1. Bahwa diperlukan pemahaman pada kelompok masyarakat tentang arti penting sistem hukum waris yang berlaku di Indonesia mulai dari berlaku pluralisme hukum (legal pluralism) sampai dengan pluralisme system kekeluargaan khususnya yang terkait dengan sistem penarikan garis keturunan. Hal ini untuk memberikan kesadaran akan arti penting hukum waris dalam kerangka memberikan perlindungan hukum serta kepastian hukum terhadap para ahli waris.

2. Dalam upaya memperoleh haknya atas harta waris, masyarakat juga harus di berikan pengetahuan tentang prosedur yang harus dilalui salah satunya pengajuan permohonan penetapan ahli waris kepada Pengadilan Agama.

3. Dalam penyelesaian sengketa waris pada dasarnya dapat dilakukan baik di dalam maupun diluar pengadilan. Akan tetapi, pada sengketa waris Desa Kepulungan, Kecamatan Gempol, Kabupaten Pasuruan, direkomendasikan untuk diselesaikan di luar pengadilan artinya diselesaikan secara musyawarah berdasarkan prinsip kekeluargaan.

\section{SARAN}

Melihat permasalahan tentang waris, serta mempertimbakan dinamika yang terjadi pada kelompok masyarakat di Desa Kepulungan, Kecamatan Gempol, Kabupaten Pasuruan, dirasa perlu untuk dikembangkan kegiatan pengabdian pada masyarakat sejenis di beberapa daerah lainnya. Hal ini bertujuan untuk memberikan pemahaman yang lebih luas kepada masyarakat akan arti penting hukum waris dengan segala turunannya dalam kerangka memberikan perlindungan hukum serta kepastian hukum terhadap masyarakat khususnya para ahli waris

\section{UCAPAN TERIMA KASIH}

Terima kasih kami sampaikan kepada Kepala Lembaga Penelitian dan Pengabdian Masyarakat, Universitas Wijaya Putra atas dukungan dan kesempatan dalam melaksanakan kegiatan pengabdian masyarakat di Desa Kepulungan, Kecamatan Gempol, Kabupaten Pasuruan. Ucapan terima kasih juga kami sampaikan kepada penyelenggara atas kesempatannya untuk bergabung dalam Konferensi Nasional ke 5 PKM-CSR tahun 2019.

\section{DAFTAR BACAAN}

Soepomo, Bab-bab Tentang Hukum Adat, Pradnya Paramita, Jakarta, 1987.

John Griffiths, What is Legal Pluralism, Jurnal of Legal Pluralismad Unoffcial Law, No. 24, 1986.

Mohammad Yasir Fauzi, Legislasi Hukum Kewarisan di Indonesia, Jurnal Pengembangan Masyarakat Islam, Volume 9, Nomor 2, Agustus 2016.

Uswatun Hasanah, Mohammad Amir Hamzah, Mufarrijul Ikhwan, Pluralisme Hukum Dalam Penyelesaian Sengketa Warisan Pada Masyarakat Madura, Jurnal Arena Hukum, Volume 11, Nomor 1, April 2018.

Agus Sudaryanto, Aspek Ontologi Pembagian Waris Dalam Hukum Islam Dan Hukum Adat Jawa, Ekonomi, Sosial, dan Budaya 
Jurnal Mimbar Hukum, Volume 22, Nomor 3, Oktober 2010.

Roihan A. Rasyid, Hukum Acara Peradilan Agama, Rajawali Press, Jakarta, 1991.

M. Yahya Harahap, Hukum Acara Perdata Tentang Gugatan, Persidangan, Penyitaan, Pembuktian dan Putusan Pengadilan.

Undang-undang Nomor 1 Tahun 1974 tentang Perkawinan.

Undang-undang Nomor 3 Tahun 2006 tentang Perubahan atas Udangundang Nomor 7 Tahun 1989 tentang Peradilan Agama.

Instruksi Presiden (Inpres) Nomor 1 Tahun 1991 tentang Kompilasi Hukum Islam (KHI). 